\title{
INITIAL DEVELOPMENT OF FIVE TREE SPECIES NATIVE TO THE ATLANTIC FOREST IN RECOMPOSITION PLANTATIONS IN SOUTHERN BRAZIL
}

\author{
Charles Rodrigo Belmonte Maffra ${ }^{1 *}$, Felipe Turchetto ${ }^{2}$, Edison Bisognin Cantarelli ${ }^{2}$ \\ ${ }^{1 *}$ Universidade Federal de Santa Maria, Programa de Pós-Graduação em Engenharia Florestal, Santa Maria, Rio Grande do Sul, Brasil - \\ charles.maffra@gmail.com \\ ${ }^{2}$ Universidade Federal de Santa Maria, Departamento de Engenharia Florestal, Frederico Westphalen, Rio Grande do Sul, Brasil - \\ felipe.turchetto@ufsm.br, engedison@yahoo.com
}

Received for publication: 07/06/2019 - Accepted for publication: 20/10/2020

\begin{abstract}
Resumo
Desenvolvimento inicial de cinco espécies arbóreas nativas da mata atlântica em plantios de recomposição florestal no sul do brasil. A regularização de propriedades rurais, aos moldes do Novo Código Florestal, depende do estudo silvicultural de espécies nativas dos biomas brasileiros. Assim, o objetivo deste estudo foi caracterizar o desenvolvimento inicial de cinco espécies arbóreas nativas da Mata Atlântica com vistas à sua utilização em projetos de recomposição e aproveitamento florestal em propriedades rurais. As seguintes espécies foram plantadas e avaliadas quanto ao desenvolvimento: Araucaria angustifolia, Mimosa scabrella, Trichilia claussenii, Schizolobium parahyba e Cordia trichotoma. Essas espécies foram conduzidas em dois experimentos distintos, tomando-se por base o delineamento experimental de blocos casualizados. No experimento 1, as espécies $A$. angustifolia, $M$. scabrella e $C$. Trichotoma foram distribuídas em 3 blocos casualizados, sendo cada um composto por 11 plantas de cada espécie.; no experimento 2 , as espécies $A$. angustifolia, $M$. scabrella, T. calussenii e $S$. parahyba foram distribuídas em 3 blocos casualizados, sendo cada um composto por 5 plantas de cada espécie. De modo geral, S. parahyba e M. scabrella apresentaram desenvolvimento mais acelerado que as demais espécies, e nesse quesito, a princípio, podem ser apresentadas como promissoras para a constituição ou reconstituição de áreas florestais em que exista interesse de se obter retorno econômico em menor espaço de tempo. A. angustifolia e T. claussenii demonstraram desenvolvimento relativamente baixo, ao passo que $C$. trichotoma, demonstrou desenvolvimento intermediário em relação às demais espécies estudadas. Apesar das diferenças de desempenho, todas as espécies se mostraram adequadas para uso em plantios de recomposição florestal principalmente para a região em que o estudo foi desenvolvido. Palavras-chave: espécies florestais, plantio florestal, silvicultura sustentável, Reserva Legal.
\end{abstract}

\begin{abstract}
The regularization of rural properties in the molds of the New Forest Code depends on the silvicultural study of the native species of the Brazilian biomes. The objective of this study was to evaluate the initial growth of five native tree species of the Atlantic Forest, with a view to their use in forest restoration projects. The following species were produced in the nursery, planted in the field, and evaluated for performance: Araucaria angustifolia, Mimosa scabrella, Trichilia claussenii, Schizolobium parahyba, and Cordia trichotoma. These species were distributed in two different areas, based on the randomized block experimental design. In experiment 1, the species A. angustifolia, M. scabrella, and C. trichotoma were distributed in three randomized blocks, each composed of 11 plants of each species. In experiment 2, the species A. angustifolia, M. scabrella, T. claussenii, and $S$. parahyba were distributed in three randomized blocks, each one composed of five plants of each species. In general, S. parahyba and M. scabrella showed faster development than the other species and, in this regard, are promising candidates for forest areas constitution or reconstitution in which there is interest in obtaining economic returns in less time. Araucaria angustifolia and $T$. claussenii showed relatively low development, whereas $C$. trichotoma showed intermediate development in relation to the other species studied. Despite their differences in performance, all species proved to be suitable for use in reforestation, mainly in the region where the study was developed.

Keywords: forest species, forest planting, sustainable silviculture, Legal Reserve.
\end{abstract}

\section{INTRODUCTION}

Brazil is known for being a country with continental characteristics, possessing a very rich biodiversity that is unparalleled in any other part of the globe. It is also known as one of the largest producers of agricultural commodities in the world, having achieved this condition due to the demands of a growing world population, which currently stands at 7.5 billion people (POPULATION PYRAMID, 2019).

In order to take advantage of the economic opportunity generated by the demand for food, agricultural production has been increasingly encouraged and intensified in recent years, which in turn has taken a considerable environmental toll in the country (GARCÍA-ORTH; MARTÍNEZ-RAMOS, 2011 ). This can be seen in the

FLORESTA, Curitiba, PR, v. 51, n. 1, p. 070-079, jan/mar 2021.

Maffra, C. R. B. et.al.

ISSN eletrônico 1982-4688

DOI: $10.5380 /$ rf.v51 i1. 67317 
expansion of agricultural frontiers, which, year after year, have reduced the habitat of many native species and, in some cases, severely and irreversibly degraded some of the main phytoecological regions of the country (MESQUITA, 2018).

Among the Brazilian biomes, the Atlantic Forest appears to be one of the most affected (BERTACCHI et al., 2016), requiring urgent practical measures to assist in policies for the correction and/or reduction of the damage already caused.

The measures adopted to recover a degraded area must consider the possibility that people who live on the land can, if they so wish, obtain some economic or other benefit from their actions of conserving and/or aiding in the recovery of degraded environments, which can perhaps be made along the lines of payments for environmental services (BRASIL, 2011). This understanding is fundamental, as it results in an incentive to adopt conservationist practices in the regularization of rural areas, in compliance with the requirements of the New Brazilian Forest Code, represented by Law No. 12,651 of May 25, 2012 (BRASIL, 2012). In this context, there is, therefore, a need to adopt practices that make areas such as, for example, those registered as legal reserves, a productive part of the property, so that they can generate more than landscape and ecological returns to their owners and the environment in which they operate.

Thus, in the context of environmental concern combined with sustainable management, it is important that practical proposals for the development of forestry activities gradually emerge. An example of this are the works that help in decision-making in relation to the tree species to be used in planned plantings, such as describing their initial development for the study region, indicating a priori that the species can stand out as species of ecological importance, and demonstrating the possibilities of short-term or long-term utilization, including using wood or non-wood products.

Contributing to the technical-scientific knowledge of native forest species that can be used in different situations on rural properties is a claim that must initially be developed at the local or regional level. In this sense, the objective of the present work was to evaluate the initial development of five native tree species from the Atlantic Forest, in the Alto Uruguai, Rio Grande do Sul (RS) region, with a view to their use in recomposing areas such as, for example, the Legal Reserve.

\section{MATERIALS AND METHODS}

\section{Study area}

The study site has an area of 4.25 ha and is located in the municipality of Frederico Westphalen, in the Middle Upper Uruguay region, in an area belonging to the Federal University of Santa Maria (27 23 '31'S and $53^{\circ} 25^{\prime} 32^{\prime \prime} \mathrm{W}$ ), approximately $480 \mathrm{~m}$ above sea level (Figure 1).

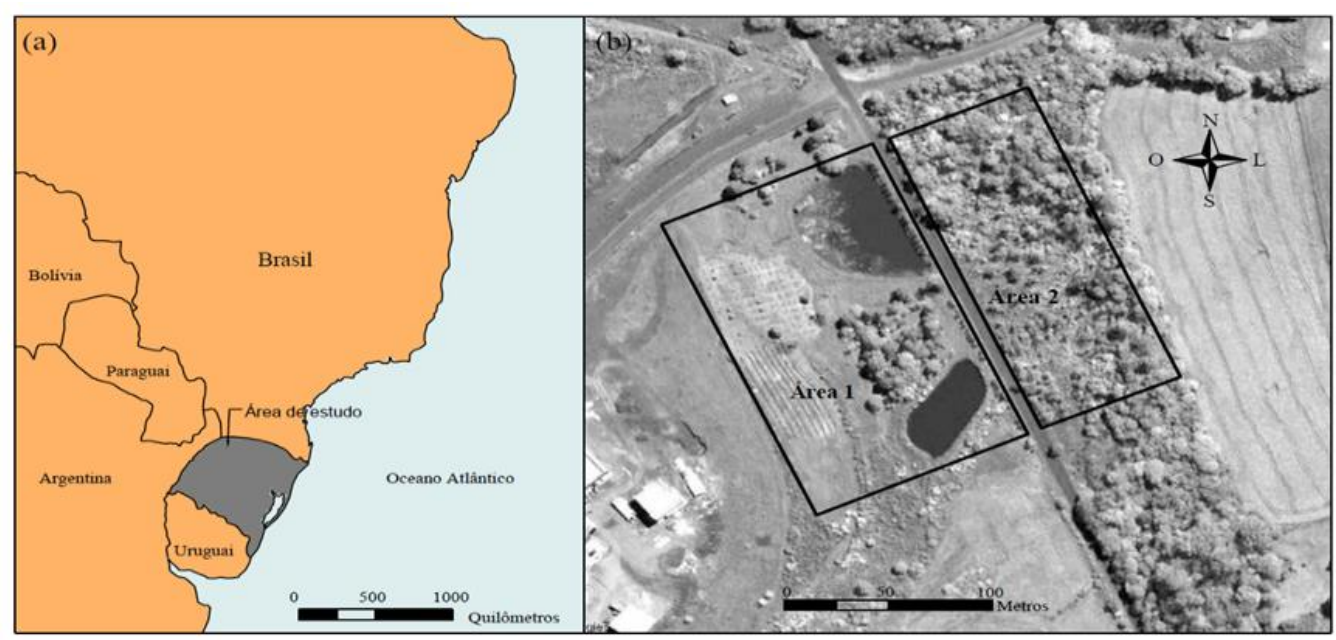

Figura 1. Localização do local de estudo (a) e vista das áreas onde os experimentos foram conduzidos (b). Fonte: Google Earth.

Figure 1. Location of the study site (a) and view the areas where the experiments were conducted. Source: Google Earth.

The climate of the region, according to the Köppen climate classification, is of the Cfa type (Subtropical Humid). The average annual rainfall ranges from 1,900 to 2,200 $\mathrm{mm}$ and is well distributed throughout the year. The maximum temperatures are greater than or equal to $22^{\circ} \mathrm{C}$ and the minimum of the coldest months is between $-3^{\circ} \mathrm{C}$ and $17^{\circ} \mathrm{C}$ (ALVARES et al., 2013). In the region, there is a predominance of dystrophic red latosols, which

FLORESTA, Curitiba, PR, v. 51, n. 1, p. 070-079, jan/mar 2021. 
are characterized as deep, homogeneous, and well-drained (CUNHA et al., 2009). As these soils are very weathered, they have a predominance of kaolinite and iron oxides, in addition to a low cation exchange capacity (STRECK et al.,2008). They also have marked acidity, low nutrient reserves, and aluminum toxicity for plants.

\section{Plant material and experimental design}

The native tree species used in the experiment were selected based on the growth speed, suitability for full sun positions and competition with other species, potential for use as a source of raw material, and potential in the restoration of degraded areas. In total, five native forest species from the Atlantic Forest Biome were used (Table 1).

Tabela 1. Lista das cinco espécies nativas da Mata Atlântica utilizadas no experimento.

Table 1. List of the five native species of the Atlantic Forest used in the experiment.

\begin{tabular}{llll}
\hline Scientific name & Common name & Family & Successional group \\
\hline Araucaria angustifolia (Bertol.) Kuntze & Araucária & Araucariaceae & Pioneer \\
Cordia trichotoma Vell. Arrab. ex Steud & Louro-pardo & Boraginaceae & Initial secondary \\
Mimosa scabrella Benth. & Bracatinga & Fabaceae & Pioneer \\
Schizolobium parahyba Vell. Blake. & Guapuruvu & Fabaceae & Pioneer \\
Trichilia claussenii C. DC. & Catiguá vermelho & Meliaceae & Late secondary \\
\hline
\end{tabular}

The seedlings were produced in the forest nursery of the Federal University of Santa Maria, Frederico Westphalen campus, from seeds of matrix trees previously selected by evaluating their morphological and health characteristics.

Experiment 1: Planting species in full sun (area 1)

Experiment 1 was conducted in a randomized block design, with Araucaria angustifolia, Mimosa scabrella, and Cordia trichotoma tested. The species were planted in three randomized blocks, each composed of 11 individuals of each species, totaling 33 individuals per block. The area was previously used for agricultural and, at the time of planting, was characterized by the presence of native grasses.

\section{Experiment 2: Enrichment planting (area 2)}

For experiment 2, a randomized block design was used, with the assayed species A. angustifolia, $M$. scabrella, Schizolobium parahyba, and Trichilia claussenii divided into three blocks. In each block, five individuals of each species were used, totaling 20 individuals per block. Prior to planting, the area consisted of Eucalyptus grandis plantings, with intense regeneration of native species, which was explored one year before the intervention. At the time of planting, the area was in an initial stage of regeneration.

In both experiments, the species were planted in pits $30 \mathrm{~cm}$ deep by $30 \mathrm{~cm}$ wide, spaced $5 \mathrm{~m}$ x $5 \mathrm{~m}$. Before planting, $100 \mathrm{~g}$ of NPK fertilizer (10-20-20) per hole were added and incorporated into the soil, in order to favor the initial development of the seedlings. The control of spontaneous plants was carried out by manual weeding at a radius of $50 \mathrm{~cm}$ around each seedling every two months. The control of leaf-cutting ants of the genera Atta and Acromyrmex was performed systematically in the total area of the experiment with the use of sulfuride-based ant killer bait.

\section{Data collection and analysis}

Data were collected at the end of the first year of development of the field plants. In both experiments, data were collected on the diameter at the root collar (DC) and the total height $(\mathrm{H})$. For the measurements of the DRC, a digital caliper was used, and for the measurement of $\mathrm{H}$, a graduated ruler was used, using the apical yolk as the standard. From the DC and $\mathrm{H}$ data, the H/DC ratio of each species was determined.

The data obtained in each experiment were subjected to an analysis of the assumptions of normality and homogeneities of variances. Subsequently, they were subjected to an analysis of variance; when a significant difference was found between treatments, a comparison test of means was performed using the Tukey test, with a level of probability of error of 0.05 . The analyses were performed using the SISVAR program (FERREIRA, 2014). 


\section{RESULTS}

\section{Experiment 1: Planting species in the full sun}

Through the analysis of variance, a significant effect of species was found $(\mathrm{p}<0.05)$ for all the variables analyzed, with the best growth results observed for M. scabrella (Figure 2).
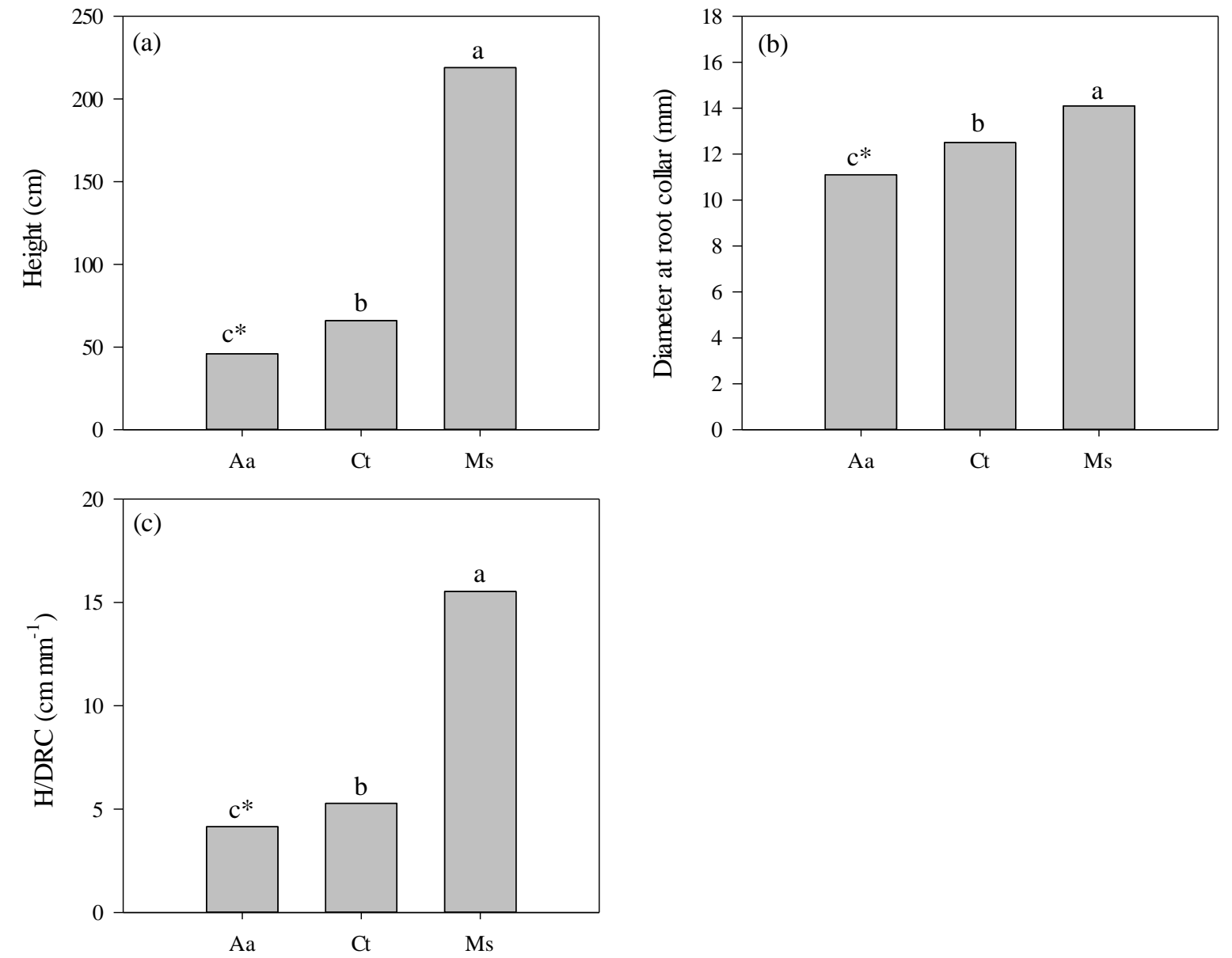

Figura 2. Crescimento em altura (a), diâmetro do coleto (b) e relação entre altura / diâmetro do coleto (c) de três espécies florestais nativas, aos 12 meses após o plantio em área de recomposição florestal a pleno sol, no extremo sul do Bioma Mata Atlântica. Onde: $\mathrm{Aa}=$ Araucaria angustifolia $; \mathrm{Ct}=$ Cordia trichotoma $; \mathrm{Ms}$ = Mimosa scabrella. *Comparação de médias por meio de Teste Tukey a 5\% de probabilidade de erro.

Figure 2. Growth in height (a), diameter at root collar (b) and height / diameter at root collar ratio (c) of three native forest species, at 12 months after planting in a forest restoration area in full sun, at the southern of Mata Atlantic Biome. Where: $\mathrm{Aa}=$ Araucaria angustifolia $; \mathrm{Ct}=$ Cordia trichotoma $; \mathrm{Ms}=$ Mimosa scabrella. * Comparison of averages using the Tukey Test at 5\% error probability.

Among the three species planted in the area, the lowest coefficient of variation (CV) for DC was observed for the species A. angustifolia $(\mathrm{CV}=8.64 \%)$, followed by $M$. scabrella $(\mathrm{CV}=13.72 \%)$ and $C$. trichotoma $(\mathrm{CV}=$ $15.63 \%)$. Thus, it can be seen that all species presented a low coefficient of variation, which indicates a similar growth of individuals from each of the three species planted in the study area, demonstrating that, after one year, no external factor interfered negatively in the development of each species.

For growth in H, C. trichotoma and A. angustifolia presented with CVs below $16.7 \%$, indicating a similar growth among individuals of the same species. The lowest $\mathrm{CV}$ was observed for $C$. trichotoma $(\mathrm{CV}=11.63 \%)$, followed by $A$. angustifolia $(\mathrm{CV}=16.65 \%)$, while $M$. scabrella had the highest value $(\mathrm{CV}=24.63 \%)$.

The high CV value presented by M. scabrella is an indication that some biotic or abiotic environmental factors influenced its height development. This was proven when it was found that bees of the species Trigona spinipes (Hymenoptera: Apidae), also known as irapuá, caused damage along the stems and branches of the plants (Figures $3 \mathrm{a}$ and $3 \mathrm{~b}$ ). In some cases, this damage, which was generally restricted to the bark, resulted in the complete annealing of the stem, causing it to break (Figure 3c).

FLORESTA, Curitiba, PR, v. 51, n. 1, p. 070-079, jan/mar 2021. 

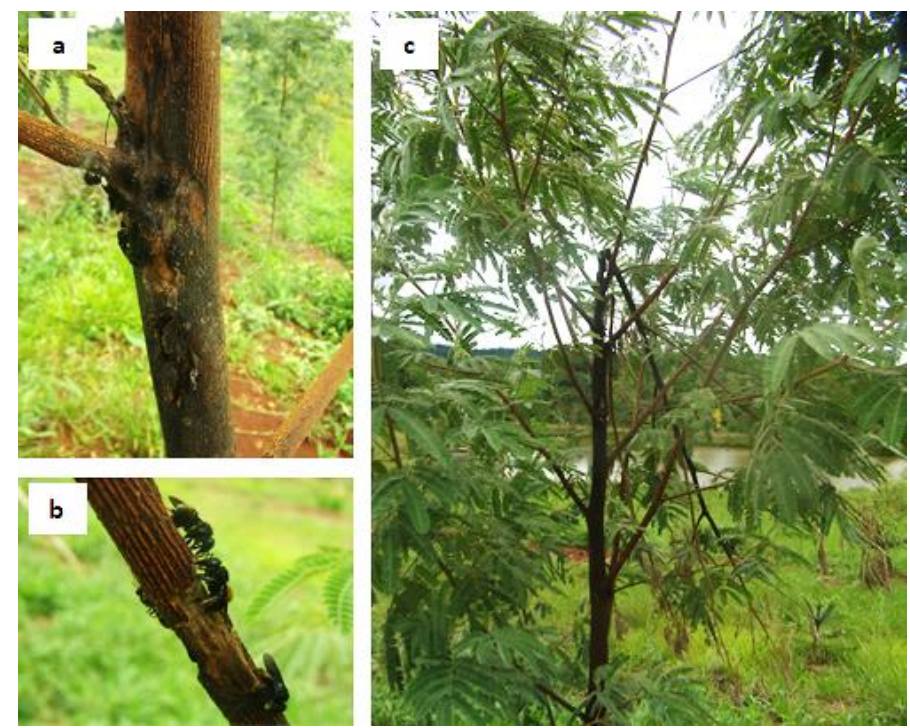

Figura 3. Aspectos do ataque de Trigona spinipes a um indivíduo de Mimosa scabrella na Área 2, um ano após o plantio. (a) Ataque realizado ao tronco da planta. (b) Ataque a um galho. (c) Planta com o tronco quebrado em decorrência do ataque dos insetos.

Figure 3. Aspects of Trigona spinipes attack on a Mimosa scabrella in Area 02, one year after planting. a) attack on plant trunk; b) attack on a branch; c) Trunk broken as a result of insect attack.

Despite the attack by insects, $M$. scabrella had the highest average height at the end of the first year of development, differing statistically from the other species. In this case, it is noted that $M$. scabrella has an initial characteristic of investing mainly in height, with growth approximately three and five times greater than that of $C$. trichotoma and A. angustifolia, respectively. The general development aspects of the three species one year after planting in an area under full sun can be seen in Figure 4.
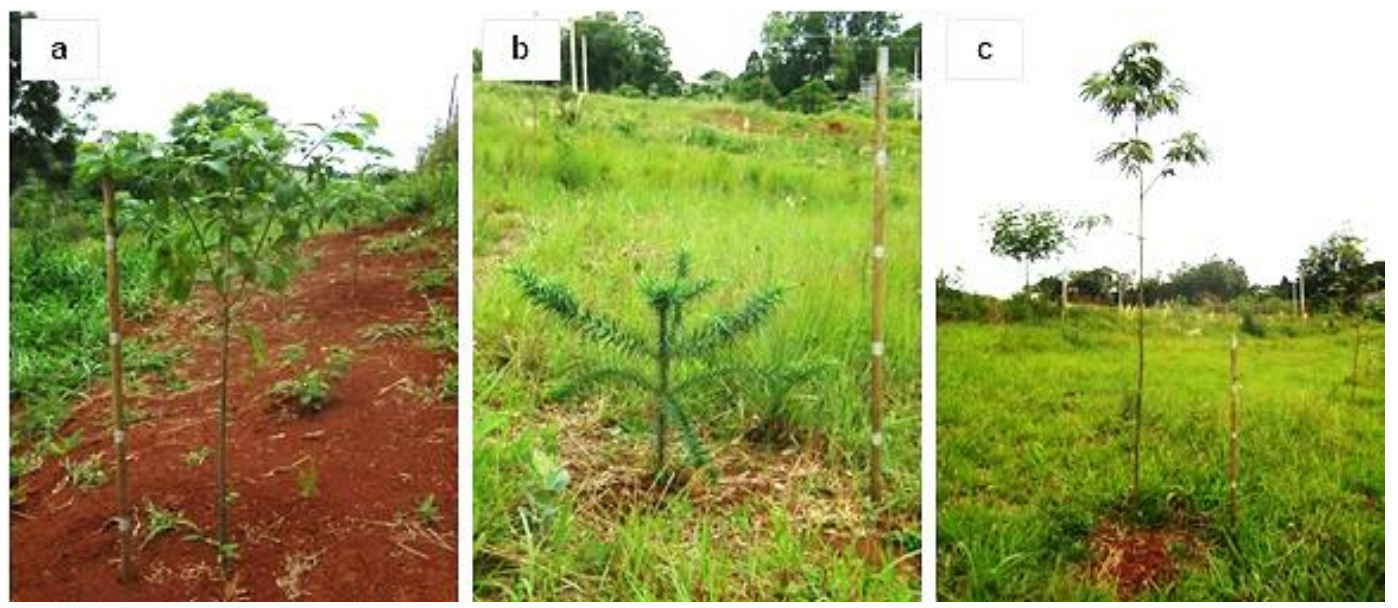

Figura 4. Aspectos gerais do desenvolvimento das espécies Cordia trichotoma (a), Araucaria angustifolia (b) e Mimosa scabrella, aos 12 messes após o plantio em área de recomposição florestal a pleno sol, no extremo sul do Bioma Mata Atlântica. Ao lado das plantas, a escala de referência tem $1 \mathrm{~m}$ de altura.

Figure 4. General aspects of the species Cordia trichotoma (a), Araucaria angustifolia (b) and Mimosa scabrella (c), at 12 months after planting in a forest restoration area in full sun, at the southern of Mata Atlantic Biome. Beside the plants, the reference scale is $1 \mathrm{~m}$ high.

\section{Experiment 2: Enrichment planting}

The analysis of variance showed a significant difference in the growth in $\mathrm{H}, \mathrm{DC}$, and H/DC ratio of the tested forest species $(\mathrm{p}<0.05)$. With regard to $\mathrm{H}$, the highest value was found for M. scabrella plants, followed by $S$. parahyba, which were the only ones with an average height greater than $100 \mathrm{~cm} 12$ months after planting (Figure 5a). Additionally, all species showed a CV below 15\%, highlighting the same quality of development. The

FLORESTA, Curitiba, PR, v. 51, n. 1, p. 070-079, jan/mar 2021. 
lowest CV was observed for S. parahyba $(\mathrm{CV}=11.42 \%)$, followed by $M$. scabrella $(\mathrm{CV}=12.24 \%), T$. claussenii $(\mathrm{CV}=12.56 \%)$, and $A$. angustifolia $(\mathrm{CV}=14.58 \%)$. In this case, it is noted that the variations in $\mathrm{H}$ were relatively small and the $\mathrm{CV}$ values were similar.
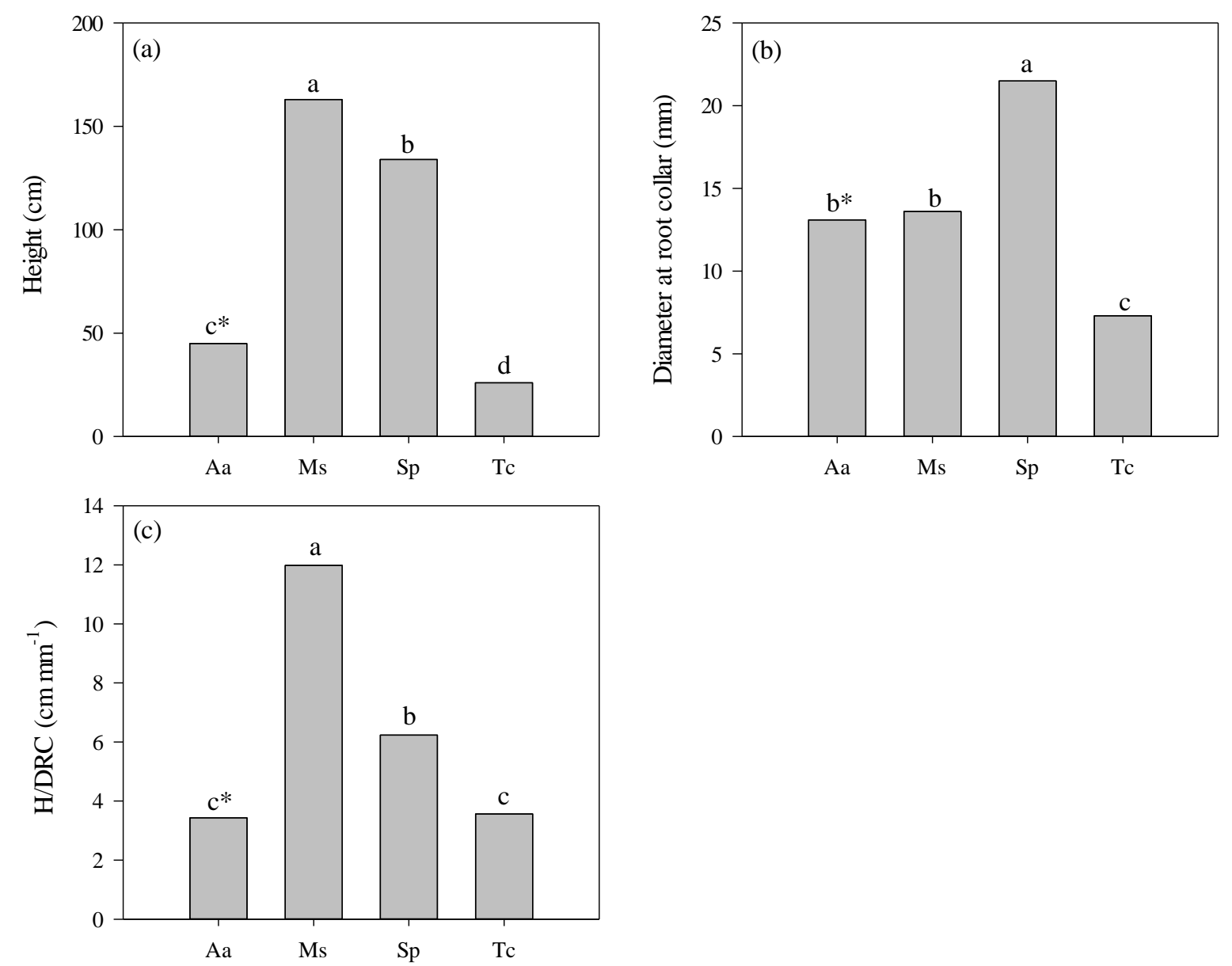

Figura 5. Crescimento em altura (a), diâmetro do coleto (b) e relação entre altura / diâmetro do coleto (c) de quatro espécies florestais nativas, aos 12 meses após o plantio em área de recomposição florestal a pleno sol, no extremo sul do Bioma Mata Atlântica. Onde: Aa = Araucaria angustifolia; Ms = Mimosa scabrella; $\mathrm{Sp}$ = Schizolobium parahyba $; \mathrm{Tc}=$ Trichilia claussenii. Comparação de médias por meio de Teste Tukey a $5 \%$ de probabilidade de erro.

Figure 5. Growth in height (a), diameter at root collar (b) and height / diameter at root collar ratio (c) of four native forest species, at 12 months after planting in a forest restoration area in full sun, at the southern of Mata Atlantic Biome. Where: Aa = Araucaria angustifolia; $\mathrm{Ms}=$ Mimosa scabrella; $\mathrm{Sp}=$ Schizolobium parahyba; $\mathrm{Tc}=$ Trichilia claussenii. * Comparison of averages using the Tukey Test at 5\% error probability.

When the DC was analyzed, the highest mean was observed for $S$. parahyba (Figure 5b). On the other hand, the lowest mean neck diameter was observed for $T$. claussenii at $0.73 \mathrm{~cm}$, a value that differed statistically from the other species. Among the four species tested, the smallest variation in the $\mathrm{CV}$ of the neck diameter was observed for $M$. scabrella $(\mathrm{CV}=9.39 \%)$, followed by $A$. angustifolia $(\mathrm{CV}=13.51 \%)$, $T$. claussenii $(\mathrm{CV}=$ $13.94 \%)$, and $S$. parahyba $(\mathrm{CV}=15.81 \%)$. These values indicate that the plants showed little variability in their secondary growth.

The H/DRC ratio also significantly differed among species $(\mathrm{p}<0.05)$, with the highest value found for M. scabrella. The second species with the highest H/DC ratio was $S$. parahyba (Figure 5c), which corroborates with the data obtained for $\mathrm{H}$ and DC, in which such species showed the highest growth. The general aspects of the development of the four species one year after planting enrichment can be seen in Figure 6 . 

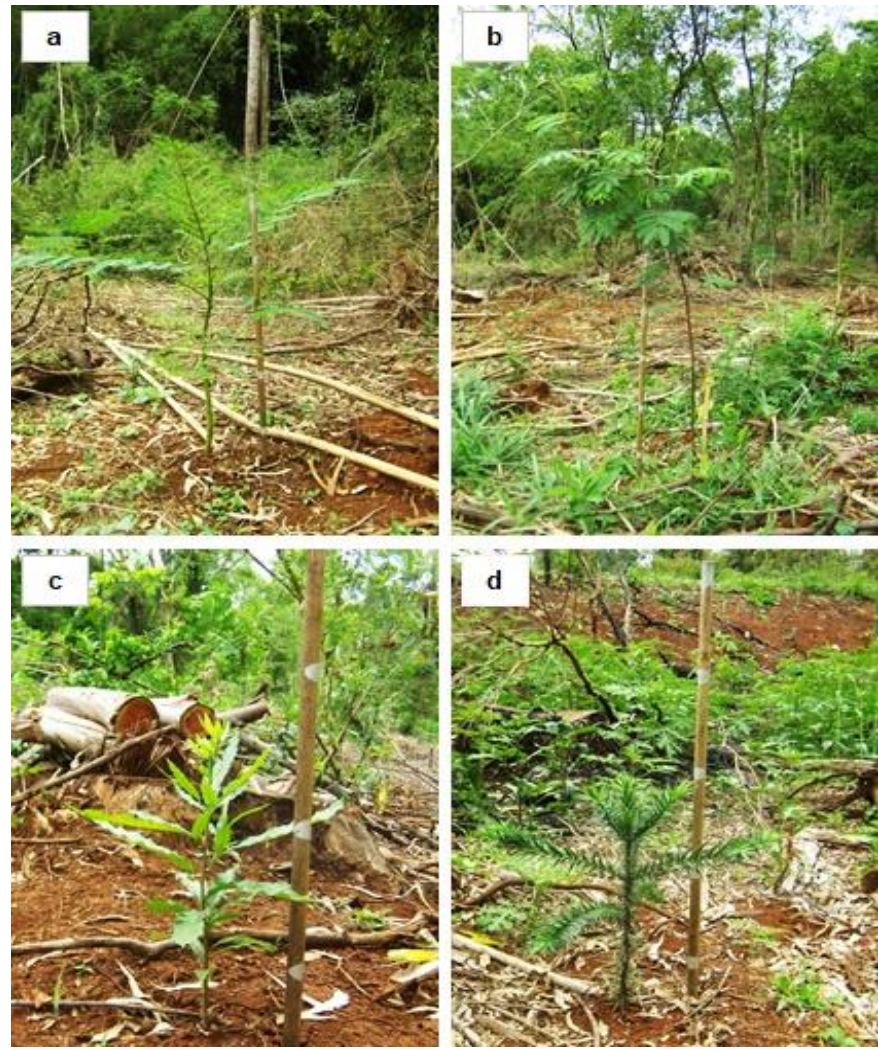

Figura 6. Aspectos gerais do desenvolvimento inicial das espécies Schizolobium parahyba (a), Mimosa scabrella (b), Trichilia claussenii (c) e Araucaria angustifolia (d), aos 12 messes após o plantio em área de recomposição florestal a pleno sol, no extremo sul do Bioma Mata Atlântica. Ao lado das plantas, a escala de referência tem $1 \mathrm{~m}$ de altura.

Figure 6. General aspects of the initial development of the species Schizolobium parahyba (a), Mimosa scabrella (b), Trichilia claussenii (c) and Araucaria angustifolia (d), at 12 months after planting in a forest restoration area in full sun, at the southern of Mata Atlantic Biome. Beside the plants, the reference scale is $1 \mathrm{~m}$ high.

\section{DISCUSSION}

\section{Experiment 1: Planting species in full sun}

The growth results of $M$. scabrella obtained in this study indicate the potential of the species to compose plantations for forest restoration, as well as the potential for plantations of homogeneous stands of the species, since it showed an increase of approximately $220 \mathrm{~cm}$ and $14 \mathrm{~mm}$ in $\mathrm{H}$ and DC, respectively, in the first year of planting in full sun. Caron et al. (2013a) evaluated the initial growth of four forest species at different spacings and found high growth rates of M. scabrella, similar to the behavior of E. grandis plants. Thus, the results indicated the high adaptability of this species to the environment and the initial grubbing of the species.

At planting, the attack of Trigona spinipes was recorded, with damage to the bark and/or breakage of branches or trunks caused by insects, negatively interfering with growth, which showed high variability among the individuals evaluated. Caron et al. (2013b) evaluated the growth of forest species in an Agroforestry system and also reported the occurrence of insect pests in M. scabrella, with a resultant high mortality rate. Therefore, in homogeneous or intercropped plantations of the species, methods of controlling Trigona spinipes should be considered to maximize the survival and growth rates of M. scabrella.

Cordia trichotoma and A. angustifolia showed lower growth rates when compared to the development of M. scabrella. Regarding A. angustifolia, Rosot et al. (2017) observed growth variation in the height from $2.0 \mathrm{~m}$ to $3.0 \mathrm{~m}$ in a mixed enrichment planting when plants were 24 months old. Tapanotti et al. (2019) evaluated the performance of timber forest species in southern Brazil and found relatively slow growth for A. angustifolia, especially in the first three years, which corroborated with the results obtained in the present study.

Cordia trichotoma is considered a priority species for composing replanting plantations in southern Brazil, and is considered a fast/moderate growth species (CORADIN et al., 2011). Rorato et al. (2018a) found $C$.

FLORESTA, Curitiba, PR, v. 51, n. 1, p. 070-079, jan/mar 2021. 
trichotoma plants with mean $\mathrm{H}$ and DC values of $87 \mathrm{~cm}$ and $12.2 \mathrm{~mm}$, respectively, at 12 months after plantation in a riparian area in the central region of Rio Grande do Sul. Berghetti et al. (2020) found higher growth rates (H $\sim 125 \mathrm{~cm}$ year $^{-1}$; DC $\left.\sim 30 \mathrm{~mm}_{\text {year }}{ }^{-1}\right)$ in C. trichotoma plants when higher phosphorus $(\mathrm{P})$ rates were provided at the time of planting. Thus, there is the potential to use the species in plantations in the southern region of Brazil in conjunction with the species' responsiveness to the use of higher doses of fertilizers at the time of planting.

In addition, it is necessary to emphasize the damage caused by frost on the development of individuals during this period. Frost, depending on the intensity, compromises the development of initial plantings (VANONI et al., 2016; TURCHETTO et al., 2020a). Rorato et al. (2018b) reported reduced growth of forest species in a forest restoration plantation in the southern tip of the Atlantic Forest Biome. In the present study, it was found that M. scabrella, A. angustifolia, and C. trichotoma managed to resume their growth after frost events, suggesting a certain tolerance to low temperatures.

\section{Experiment 2: Enrichment planting}

In this experiment, the species that stood out in terms of growth were M. scabrella and S. parahyba, with high growth rates, mainly regarding $\mathrm{H}$. The results obtained for $M$. scabrella corroborate with the results obtained from planting the species in the full sun, indicating that the species has a high potential for use in initial plantations in the full sun and to incorporate into enrichment plantations.

The results obtained in this study regarding the growth of $M$. scabrella may be related to the characteristics of the species. According to Carvalho (1994), the species is not very demanding regarding the physical and chemical conditions of the soil. In addition, the rusticity and heliophilic character of the species enables rapid coverage of altered areas or degraded soils in which their populations occur. Thus, it denotes the economic and ecological potential of the species, as it can generate income due to its rapid growth and help to improve the chemical properties of the soil, due to the large amount of nitrogen incorporated into the soil.

Schizolobium parahyba proved to be a fast-growing species, making it an interesting alternative as a covering species in forest restoration plantations. According to Coradin et al. (2011), S. parahyba is a pioneer, heliophile species, and is undemanding in edaphic conditions. Weidlich et al. (2010) evaluated the allocation of resources in the initial development of $S$. parahyba seedlings and found high levels of soluble sugars allocated to epicotyls, which are necessary to enable the fast growth of $S$. parahyba as a pioneer species. These characteristics may explain, at least partially, its advantage in relation to the other species.

The species with the lowest growth rate was $T$. claussenii, which may be an expected behavior of the species. Turchetto et al. (2020b) evaluated different silvicultural techniques in a riparian forest restoration plantation in the southern tip of the Atlantic Forest Biome. They also found low growth in H and DC, regardless of the practice used. According to Coradin et al. (2011), the species generally occurs in fertile soils that are rich in organic matter, preferably in areas of closed forests at an advanced stage of regeneration, where it constitutes the medium stratum of the vegetation. Thus, when introducing the species $T$. claussenii in areas of forest restoration, one should choose to enrich plantings at a more advanced stage, in which the existing crowns intercept most of the light energy.

Additionally, for the DC variable, all species showed coefficients of variation below $16 \%$, indicating that there was a similar growth rate of individuals of each species. In addition, it demonstrated that, in a year of development in the field, no external factors (such as insects, weeds, competition, or climate) negatively affected their development. It is possible that this result is associated with a greater diversity of plants in the area, which is enriched, and also with the organic cover existing in the soil resulting from the remains of the E. grandis harvest that was carried out before planting. In addition to the contribution of these factors, the species planted in the area received protection against the weather conditions provided by the largest trees (understory native and exotic trees between 5-10 m high), which were not removed in the harvest of Eucalyptus sp.

In the study of native species for use in rural properties, it should be noted that the objective of studying the development of plants should not only be linked to comparisons among the development of species and/or the quality of their wood products. It must also be considered that native species can provide, in addition to ecological benefits for the places where they are planted (such as improving the microclimate, combating erosion, and providing food and shelter for fauna), differentiated products, such as edible seeds and flowers for the production of honey. In addition, it is important to emphasize that in order to acquire more information about the initial growth of these species, it is necessary to extend the observation time and carry out additional studies in other subtropical regions. 


\section{CONCLUSIONS}

- Schizolobium parahyba and M. scabrella were the species with the most accelerated development, and for that reason they have potential as promising species for the constitution or reconstitution of forest areas and for eventually obtaining income in less time.

- Araucaria angustifolia and T. claussenii showed relatively slow development, while C. trichotoma was demonstrated to be a species of average development compared with the other species.

- Regarding their morphological characteristics, M. scabrella developed a lot in height, which was associated with the attacks of the bee Trigona spinipes, resulting in the breaking of branches and/or the trunk of plants, a condition that requires special care in relation to the staking of seedlings and controlling insect activity. The other species showed a lower H/DC ratio, which influenced the greater stability of their stems.

- Despite the differences in the development characteristics of the five species tested, all can be considered promising for use in forest restoration plantations in the study region. The composition of stands with different species tends to result in important contributions to the environmental and economic issues of a rural property.

\section{ACKNOWLEDGEMENTS}

The authors would like to thank the National Council for Scientific and Technological Development $(\mathrm{CNPq})$ for financial assistance in the form of a research grant and necessary supplies for the execution of this work.

\section{REFERENCES}

ALVARES, C. A.; STAPE, J. L.; SENTElHAS, P.C.; GONCALVES, J. L. M.; SPAROVEK, G. Köppen's climate classification map for Brazil. Meteorologische Zeitschrift, v. 22, n. 6, p. 711 - 728, 2013.

BERGHETTI, Á. L. P.; ARAUJO, M. M.; TABALDI, L. A.; TURCHETTO, F.; AIMI, S. C.; RORATO, D. G.; MARCHEZAN, C.; GRIEBELER, A. M.; BARBOSA, F. M.; BRUNETTO, G. Morphological, physiological and biochemical traits of Cordia trichotoma under phosphorous application and a water-retaining polymer. Journal of Forestry Research, v. 31, n. 3, 2020.

BERTACCHI, M. I. F.; AMAZONAS, N. T.; BRANCALION, P. H. S.; BRONDANI, G. E.; DE OLIVEIRA, A. C. S.; DE PASCOA, M. A. R.; RODRIGUES, R. R.; Establishment of tree seedlings in the understory of restoration plantations: Natural regeneration and enrichment plantings. Restoration Ecologycol, Washington, v. 24, p. 100-108, 2016.

BRASIL. Ministério do Meio Ambiente. Secretaria de Biodiversidade e Florestas. Departamento de Conservação da Biodiversidade. Pagamentos por serviços ambientais na Mata Atlântica: lições aprendidas e desafios. Brasília: MMA, 2011. 280p.

BRASIL. Lei no 12.651 , de 25 de maio de 2012. Dispõe sobre a proteção da vegetação nativa; altera as Leis nos 6.938, de 31 de agosto de 1981, 9.393, de 19 de dezembro de 1996, e 11.428, de 22 de dezembro de 2006; revoga as Leis nos 4.771, de 15 de setembro de 1965, e 7.754, de 14 de abril de 1989, e a Medida Provisória no 2.166-67, de 24 de agosto de 2001; e dá outras providências. Diário Oficial da União, Brasília, DF, vinte cinco de maio de 2012. Available at: 〈http://www.planalto.gov.br/ccivil_03/_Ato2011-2014/2012/Lei/L12651.htm〉. Acesso em: 01 March 2019.

CARON, B. O.; MANFRON, P. A.; DE SOUZA, V. Q.; COSTA, E. C.; ELOY, E.; BEHLING, A.; DENARDI, L. Crescimento inicial de quatro espécies arbóreas em diferentes espaçamentos. Revista Agropecuária Catarinense, Florianópolis, v. 26, n. 2, p. 58-60, 2013a.

CARON, O.; SOUZA, Q.; SCHMIDT, A.; ELOY, E.; ELLI, E. F. Movimentação de Trigona spinipes (Fabricius) na Mimosa scabrella (Bentham) em função de fatores climáticos. Comunicata Scientiae, v. 4, n. 3, p. 270-276, 2013b.

CARVALHO, P. E. R. Espécies florestais: recomendações silviculturais, potencialidades e usos da madeira. Brasília: EMBRAPA, 1994. 640p.

CORADIN, L.; SIMINSKI, A.; REIS, A. Espécies Nativas da Flora Brasileira de Valor Econômico Atual ou Potencial: Plantas para o Futuro - Região Sul. Brasília: MMA, 1 ed, 2011, 934p. 
CUNHA, N. G.; SILVEIRA, R. J. C.; KOESTER, E.; COSTA, F. A.; TERRES, V. C.; SILVA, J. B.; JUNIOR, J. T. B. Estudo dos solos de municípios do Alto Uruguai, RS. Embrapa Clima Temperado, Circular Técnica 88, 2009, 50p.

FERREIRA, D. F. Sisvar: A guide for its bootstrap procedures in multiple comparisons. Ciência e Agrotecnologia, v. 38, n., p. 109-112, 2014.

GARCÍA-ORTH, X.; MARTÍNEZ-RAMOS, M. Isolated trees and grass removal improve performance of transplanted Trema micrantha (L.) Blume (Ulmaceae) saplings in tropical pastures. Restoration Ecology, Washington, v. 19, n. 1, p. 24-34, 2011.

MESQUITA, B. A. An expansão da fronteira agrícola num cenário de globalização da agricultura Revista de Políticas Públicas, p. 1076-1098, 2018.

POPULATION PYRAMID. World. Available at: http: //www. populationpyramid. net/> Acesso em: 12 de maio de 2019.

RORATO, D. G.; ARAUJO, M. M.; TABALDI, L. A.; TURCHETTO, F.; BERGHETI, Á. L. P.; GRIEBELER, A. M.; BARBOSA, F. M.; AIMI, S. C. Silvicultura com espécies florestais nativas mediante o plantio de mudas: um experiência em áreas ripárias no sul do Brasil. In: ARAUJO, M. M.; NAVROSKI, M. C.; SCHORN, L. A. Produção de sementes e mudas: Um enfoque a silvicultura. Santa Maria: Ed. UFSM, 2018a, 448p.

RORATO, D. G.; ARAUJO, M. M.; TABALDI, L. A.; TURCHETTO, F.; GRIEBELER, A. M.; BERGHETTI, Á. L. P.; BARBOSA, F. M. Tolerance and resilience of forest species to frost in restoration planting in southern Brazil. Restoration Ecology, Washington, v. 26, p. 537-542, 2018b.

ROSOT, M. A. D., FRANCISCON, L.; MARAN, J. C.; ROSOT, N. C.; CARDOSO, D. C. Desempenho de Araucaria angustifolia em plantios de enriquecimento usando diferentes tamanhos de mudas. EMBRAPA, Comunicado técnico, Colombo, p. 1-8, 2017.

STRECK E.V.; KAMPF, N.; DALMOLIN, R. S. D.; KLAMT, E.; NASCIMENTO, P. C. do; SCHNEIDER, E.; PINTO, L. F. S. Solos do Rio Grande do Sul, 2. ed. Porto Alegre: EMATER/RS - ASCAR, 2008. 222 p.

TOPANOTTI, L. R.; GERBER, D.; STOLARSKI, O. CARLOS.; TRENTIN, B. E.; PERTILLE, C. T.; SCHORR, L. P. B.; GORENSTEIN, M. R.; NICOLETTI, M. F.; BECHARA, F. C. Initial growth performance of valuable timber species in southern BRAZIL: Araucaria angustifolia, Balfourodendron riedelianum, and Parapiptadenia rigida. Revista Árvore, Viçosa, v. 43, n. 4, p. 1-10, 2019.

TURCHETTO, F.; ARAUJO, M. M.; GRIEBELER, A. M.; RORATO, D. G.; BERGHETTI, Á. L. P.; BARBOSA, F. M.; LIMA, M. S. Can intensive silvicultural management minimize the effects of frost on restoration plantations in subtropical regions? Journal of Environmental Management, London, v. 269, 2020a.

TURCHETTO, F.; ARAUJO, M. M.; TABALDI, L. A.; GRIEBELER, A. M.; RORATO, D. G.; BERGHETTI, Á. L. P.; BARBOSA, F. M.; LIMA, M. S.; COSTELLA, C.; SASSO, V. M. Intensive silvicultural practices drive forest restoration in southern Brazil. Forest Ecology and Management, Amsterdam, v. 473, $2020 \mathrm{~b}$.

VANONI, M.; BUGMANN, H.; N€OTZLI, M.; BIGLER, C. Drought and frost contribute to abrupt growth decreases before tree mortality in nine temperate tree species. Forest Ecology and Management, Amsterdam, v. 382, p. 51-63, 2016.

WEIDLICH, E. W. A.; PESCADOR, R.; UHLMANN, A. Resource allocation (carbohydrates) in the initial development of seedlings of Schizolobium parahyba (Vell.) S.F. Blacke (Fabaceae-Caesalpinioideae). Revista Árvore, Viçosa, v. 34, n. 4, p. 627-635, 2010.

FLORESTA, Curitiba, PR, v. 51, n. 1, p. 070-079, jan/mar 2021.

Maffra, C. R. B. et.al.

ISSN eletrônico 1982-4688

DOI: $10.5380 /$ rf.v51 i1. 67317 